\title{
Analisis Pengembangan Usaha Tani Kakao Di Desa Taulo Kecamatan Alla Kabupaten Enrekang
}

\author{
Analysis of Cocoa Farming Business Development in Taulo Village, Alla District, Enrekang \\ Regency
}

\author{
Mirnawati $^{*}$, Andi Nuddin', ${ }^{1}$ Yusriadi $^{1}$ \\ "Email: mirnawatinasri@gmail.com \\ ${ }^{1}$ Fakultas Pertanian, Peternakan dan Perikanan Universitas Muhammadiyah Parepare
}

Diterima: 10 September 2021 / Disetujui: 20 Desember 2021

\begin{abstract}
ABSTRAK
Penelitian ini dilaksanakan Di Desa Taulo Kecamatan Alla Kabupaten Enrekang dari bulan November 2020 sampai dengan bulan Januari 2021. Penelitian bertujuan untuk mengetahui pendapatan yang diperoleh dalam usaha tani kakao, kelayakan usaha tani kakao dan strategi pengembangannya dengan menggunakan metode analisis kelayakan dan analisis Interpretativ Stuktural Modelling ISM dengan pengambilan data melalui wawancara dengan pengisian kuisioner untuk analisis pendapatan dan kelayakan sebanyak 32 orang responden dan 16 responden untuk analisis ISM. Hasil penelitian ini menunjukan bahwa tingkat kelayakan 2,25 dan Hasil analisis ISM diperoleh program strategi yang strategis adalah : (2) Pembinaan kelompok tani/gapoktan, (1) Rehabilitas tanaman kakoa, (6) Peningkatan kualitas produk/mutu biji kakao, (4) Peningkatan peran penyuluhan, (3) Pengelolaan pasca panen, (5) Pengembangan produktivitas lahan, (8) Pengembangan pemasaran produksi, (12) pemberantasan hama dan penyakit, (11) Peningkatan sarana produksi, (10) Peningkatan agroimput, (7) Pengstabilan harga.
\end{abstract}

Kata Kunci: Usaha Tani, Kakao, Pendapatan, Tingkat Kelayakan, Strategi Pengembangan

\section{ABSTRACT}

This research was conducted in Taulo Village, Alla District, Enrekang Regency from November 2020 to January 2021. The study aims to find out how the income earned in cocoa farming is, how is the feasibility of cocoa farming and how is the development strategy using feasibility analysis methods and Interpretative analysis. ISM Structural Modeling with data collection through interviews by filling out questionnaires for income and feasibility analysis as many as 32 respondents and 16 respondents for ISM analysis. The results of this study indicate that the feasibility level is 2.25 and the results of the ISM analysis obtained that strategic strategic programs are: (2) Fostering farmer groups/gapoktan, (1) Rehabilitation of cocoa plants, (6) Improving product quality/quality of cocoa beans, (4) Increasing the role of extension, (3) Post-harvest management, (5) Development of land productivity, (8) Development of production marketing, (12) eradicating pests and diseases, (11) Increasing production facilities, (10) Increasing agro-imput, (7) Price stabilization

Keywords: Cocoa Farming, Income, Feasibility Level, Development Strategy

(c) (1) This work is licensed under Creative Commons Attribution License 4.0 CC-BY International license

\section{A. PENDAHULUAN}

Enrekang merupakan salah satu

daerah pemasok kakao di Sulawesi

Selatan namun masih lebih rendah dari

daera lain. Potensi iklim dan tanah
Kabupaten Enrekang sangat menunjang untuk pertumbuhan tanaman kakao di samping itu tanaman kakao adalah salah satu mata pencaharian petani di Enrekang dan merupakan tanaman andalan ekspor 
Indonesia. Pada tahun 2018 produksi kakao di Kabupaten Enrekang mencapai 3.159.96 ton dengan luas lahan 8.192 hektar, lahan yang tersebar di 12 Kecamatan .

Kakao merupakan tanaman tahunan yang mulai berbunga dan berbuah pada umur 3-4 tahun setelah ditanam. Apabila pengelolaan tanamn kakao dilakukan secara baik, maka masa produksinya dapat bertahan lebih dari 25 tahun. Selai itu untuk keberhasilan bududaya kakao perlu memperhatikan lahan mana yang cocok untuk tanaman kakao.

Tanaman perkebunan kakao menjadi andalan petani di Desa Taulo Kecamatan Alla Kabupaten Enrekang, tanamn ini merupakan sumber pendapatan ekonomi para petani. Sebagian besar dari produksi kakao ditujukan untuk memenuhi kebutuhan pasar ekspor sehingga diperoleh pendapatan dari kakao cukup berarti baik bagi petani maupun bagi peningkatan pendapatan asli daerah. Namun kebanyakan petani mengalami penurunan produksi karena produksi kakao di serang oleh penyakit dan hama, sehingga kebanyakan petani beralih ke komuditi lain seperti tanaman sayursayuran. Tingginya produksi kakao yang diperoleh belum tentu menjamin tingginya pendapatan petani yang akan diterima. Hal ini disebabkan karena penerimaan petani dipengaruhi terhadap harga.

Permasalahan yang diangkat dalam penelitian ini adalah :1). Berapa besar pendapatan yang diperoleh dalam kegiatan usahatani kakao di Desa Taulo, Kecamatan Alla, Kabupaten Enrekang Provinsi Sulawesi Selatan, 2). Apakah usaha tani kakao layak dikembangkan di Desa Taulo, Kecamatan Alla, Kabupaten Enrekang Provinsi Sulawesi Selatan, 3). Bagaimana strategi pengembangan usaha tani kakao di Desa Taulo, Kecamatan Alla, Kabupaten Enrekang Provinsi Sulawesi Selatan.

\section{B. METODE PENELITIAN \\ 1. Tempat dan Waktu}

Penelitian ini dilaksanakan di Desa Taulo, Kecamatan Alla, Kabupaten Enrekang Provinsi Sulawesi Selatan. Sengaja dengan pertimbangan bahwa di Desa tersebut usahatani tanaman kakao merupakan salah satu jenis usahatani dominasi dan merupakan mata pencaharian. Penelitian ini di laksanakan pada Tanggal 06 November 2020 - 06 Jannuari 2021. Alasan memilih Desa Taulo, Kecamatan Alla, Kabupaten Enrekang Provinsi Sulawesi Selatan karena sebagian besar mata pencaharian 
masyarakat yang ada di Desa Taulo yaitu petani kakao.

\section{Populasi dan Sampel}

Populasi dalam penelitian ini adalah petani yang memproduksi petani kakao dengan jumlah 162 orang yang ada di Desa Taulo, Kecamatan Alla, Kabupaten Enrekang Provinsi Sulawesi Selatan dengan suatu pertimbangan bahwa desa tersebut merupakan desa yang memproduksi tanaman kakao.

Penentuan sampel secara acak sederhana. Menurut Arikunto (2002), jika jumlah populasi <100 maka jumlah sampel $=$ jumlah populasi. Jika jumlah populasi >100 orang, maka sampel dapat diambil sebanyak 20-30\%. Sehingga sampel dalam penelitian ini sebanyak 32 orang (20\% dari 162). sampel adalah bangian dari populasi (sebagian atau wakil populasi yang diteliti)". Penentuan responden dalam penelitian ISM. Dilakukan melalui sistem ahli pakar dengan menggunakan metode survey. Penetapan responden dilakukan secara sengaja (purposive sampling), dengan ketentuan mewakili personil dibidang instansi yang terkait.

\section{Analisis Data}

Untuk mengetahui besarnya biaya, penerimaan dan pendapatan dari Analisis Pengembangan Usaha Tani Kakao di
Desa Taulo Kecamatan Alla Kabupaten Enrekang.

a. Biaya, Firdaus (2008) menyebutkan total biaya merupakan keseluruhan jumlah biaya produksi yang dikeluarkan. Untuk mengetahui total biaya secara matematis dirumuskan sebagai berikut :

$$
\mathbf{T C}=\mathbf{T F C}+\mathbf{T V C}
$$

Keterangan :

$\mathrm{TC}=$ Total biaya

$\mathrm{TFC}=$ Biaya tetap

$\mathrm{TVC}=$ Biaya tidak tetap

b. Penerimaan, Soekartawi (2006) menyatakan penerimaan usahatani adalah perkalian antara volume produksi yang diperoleh dengan harga jual. Untuk mengetahui penerimaan secara matematis dirumuskan sebagai berikut :

$$
\mathbf{T R}=\mathbf{Q} \times \mathbf{P}
$$

$$
\begin{aligned}
& \text { Keterangan: } \\
& \text { TR= Penerimaan } \\
& \mathrm{Q}=\text { Produk } \\
& \mathrm{P}=\text { Harga }
\end{aligned}
$$

c. Pendapatan, Sesuai yang dikemukakan Soekarwati (2006) pendapatan usahatani adalah selisih antara penerimaan dan semua biaya. Untuk mengetahui pendapatan secara matematis dirumuskan sebagai berikut:

$$
\pi=\mathbf{T R}-\mathbf{T C}
$$

Keterangan:

$\pi=$ Pendapatan

$\mathrm{TR}=$ Penerimaan

$\mathrm{TC}=$ Total biaya 
d. Kelayakan, Untuk mengetahui Tingkat kelayakan usahatani Kakao di Desa Taulo, Kecamatan Alla, Kabupaten Enrekang digunakan rumus Kelayakan sebagai berikut:

$$
\mathrm{R} / \mathrm{C} \text { ratio }=\frac{\mathrm{TR}}{\mathrm{TC}}
$$

Keterangan:

$\mathrm{R} / \mathrm{C}$ ratio $=$ Rasio penerimaan atas biaya $\mathrm{TR}=$ Penerimaan

$\mathrm{TC}=$ Total biaya

Kriteria yang digunakan dalam penentuan efisiensi usaha adalah:

$\mathrm{R} / \mathrm{C}>1$ berarti usaha layak untuk dijalankan,

$\mathrm{R} / \mathrm{C}=1$ berarti usaha yang dijalankan mencapai titik impas

$\mathrm{R} / \mathrm{C}<1$ berarti usaha tidak layak untuk dijalankan

e. Analisis Interpretative Structural Modeling (ISM). Teknik ISM ini ini dapat digunakan untuk melakukan analisis data. Secara garis besar teknik ISM, langkah pertama yang perlu dilakukan dalam analisis ISM adalah menentukan elemen-elemen yang sesuai dengan permasalahan yang ada. Selanjutnya disusun subelemen pada setiap elemen yang dipilih. Pemilihan elemen dan penyusunan sub elemen dilakukan dari hasil diskusi di setiap instansi yang terkait. Hasil penilaian tersebut tersusun dalam Structural Self Interaction Matrix (SSIM) yang dibuat dalam bentuk Rechability
Matrix (RM) dengan mengganti $\mathrm{V}$, A, X, O menjadi bilangan 1 dan 0 .

Dalam penelitian ini, kode responden sudah tersedia secara baku sehingga penyesuaian daftar kode tidak dilakukan. Kuisioner dalam penelitian ini telah menggunakan kode jawaban :V, A, $\mathrm{X}$ dan $\mathrm{O}$ yang bermakna :

$\mathrm{V}=$ adalah eij adalah 1 eij adala 0

$\mathrm{A}=$ adalah eij adalah 0 eij adala 1

$\mathrm{X}=$ adalah eij adalah 1 eij adala 0

$\mathrm{O}=$ adalah eij adalah 0 eij adala 0

$1=$ adalah hubungan konsektual antara elemen

0 = tidak ada hubungan konsektual antara elemen

\section{HASIL DAN PEMBAHASAN}

\section{Biaya Usaha Tani}

Biaya usahatani adalah biaya yang dikeluarkan selama proses produksi. Biaya usahatani ada yang dikelurkan pada saat melakukan proses produksi maupun tidak melakukan proses produksi. Biaya yang dikeluarkan selama melakukan kegiatan usahatani disebut variabel sedangkan biaya yang dikeluarkan meskipun tidak melakukan kegiatan usahatani disebut biaya tetap. Berikut biaya-biaya yang dikeluarkan pada usahatani tanaman kakao adalah sebagai berikut:

\section{a. Biaya Tetap (Fixes Cost)}

Biaya tetap usahatani tanaman kakao meliputi penyusutan peralatan dan pajak 
kebun kakao. Dalam proses produksi usahatani kakao, diperlukan alat-alat yang digunakan dalam mengelolah usahatani kakao, karna ketersediaan alat sangat dibutuhkan agar membuat petani labih efisien dan efektif dalam melakukan kegiatan produksi.

Tabel 1. Jenis dan rata-rata nilai penyusutan alat usahatani kakao responden di Desa Taulo Kecamatan Alla, Kabupaten Enrekang

\begin{tabular}{clcc}
\hline No & $\begin{array}{c}\text { Jenis biaya } \\
\text { yang } \\
\text { digunakan }\end{array}$ & $\begin{array}{c}\text { Jumlah } \\
(\mathbf{R p})\end{array}$ & $\begin{array}{c}\text { Rata-rata } \\
\text { per orang } \\
(\mathbf{R p})\end{array}$ \\
\hline 1. & Alat semprot & 22.500 .000 & 703.125 \\
2. & Parang & 4.880 .000 & 150.000 \\
3. & Alat panen & 1.275 .000 & 39.843 \\
4. & Terpal & 6.930 .000 & 216.562 \\
5. & Ember & 2.020 .000 & 63.125 \\
\hline \multicolumn{4}{l}{ Jumlah } \\
\hline \multicolumn{2}{l}{ Sumber : Data Primer Setelah Diolah, 2020 }
\end{tabular}

Berdasarkan Tabel 1 menunjukkan bahwa total nilai penyusutan alat yang digunakan petani responden dalam usahatani kakao Rp 37.605.000 selama 1 (satu) tahun produksi, Rp 3.133 .750 selama 1 (satu) bulan produksi, dan Rp 1.172.655 per 1 (satu) orang produksi.

Biaya tetap yang dikeluarkan oleh setiap petani dalam melakukan kegiatan produksi kakao di Desa Taulo, Kecamatan Alla, Kabupaten Enrekang dapat dilihat pada Tabel 2.
Tabel 2. Rata-rata biaya tetap yang dikeluarkan oleh Responden petani kakao di Desa Taulo Kecamatan Alla, Kabupaten Enrekang

\begin{tabular}{|c|c|c|c|}
\hline No. & Jenis Biaya Tetap & $\begin{array}{l}\text { Jumlah } \\
\text { (Rp) }\end{array}$ & $\begin{array}{c}\text { Nilai } \\
\text { Rata (Rp) }\end{array}$ \\
\hline 1. & Penyusutan Peralatan & 37.605 .000 & 1.175 .156 \\
\hline \multirow[t]{2}{*}{2.} & Pajak & 3.525 .000 & 110.156 \\
\hline & Jumlah & 41.130.000 & 1.285.312 \\
\hline
\end{tabular}

Berdasarkan Tabel 2 menunjukkan bahwa ada 2 biaya tetap yang dikeluarkan oleh setiap petani kakao yaitu pajak dan penyusutan peralatan. Maka total biaya tetap yang di keluarkan oleh petanai kakao sebesar 41.130.000 selama 1 (satu) tahun produksi, total biaya tetap yang di keluarkan oleh petani kakoa sebesar Rp 3.427.500 selama 1 bulan produksi, dan Rp 1.285.312 per 1 (satu) orang produksi. b. Biaya Tidak Tetap (Variabel Cost)

Biaya tidak tetap adalah biaya yang dikeluarkan selama melakukan kegiatan produksi. Artinya bahwa biaya ini dipengaruhi oleh jumlah produksi yang dihasilkan. Hal ini ini sesui dengan pendapatan suratiyah (2006), yang menjelaskan bahwa biaya tidak tetap adalah biaya yang digunakan pada setiap musim tanam dengan jumlah dan besarnya tergantung skala produksi. Adapun biaya tidak tetap yang digunakan petani responden dalam mengelolah usahataninya dapat dilihat pada tabel 3 . 
Tabel 3. Jenis dan rata-rata nilai biaya tidak tetap yang dikeluarkan petanai kakao responden di Desa Taulo Kecamatan Alla' Kabupaten Enrekang.

\begin{tabular}{|c|c|c|c|}
\hline \multicolumn{2}{|c|}{$\begin{array}{c}\text { Jenis Biaya Tidak Tetap } \\
\text { (Variable Cost) }\end{array}$} & \multirow{2}{*}{$\begin{array}{c}\begin{array}{c}\text { Jumlah } \\
\text { (Unit) }\end{array} \\
58.210 \text { Benih } \\
\end{array}$} & \multirow{2}{*}{$\begin{array}{l}\begin{array}{l}\text { Total biaya } \\
\text { (Rp/Tahun) }\end{array} \\
30.255 .000 \\
\end{array}$} \\
\hline Benih & $:$ & & \\
\hline & Jumlah & - & 30.255 .000 \\
\hline \multirow[t]{4}{*}{ Pupuk } & UREA & $1 \mathrm{Kg}$ & 4.750 .000 \\
\hline & SP-36 & $1 \mathrm{Kg}$ & 5.420 .000 \\
\hline & Pelangi & $1 \mathrm{Kg}$ & 5.200 .000 \\
\hline & Jumlah & - & 15.370 .000 \\
\hline \multirow[t]{3}{*}{ Obat-obatan } & Herbisida & 2 Liter & 3.220 .000 \\
\hline & Insektisida & 2 Liter & 2.360 .000 \\
\hline & Jumlah & - & 5.580 .000 \\
\hline \multirow[t]{3}{*}{ Tenaga Kerja } & Panen & 3 Orang & 6.440 .000 \\
\hline & Pengupasan & 3 Orang & 6.930 .000 \\
\hline & Jumlah & - & 13.370 .000 \\
\hline \multicolumn{2}{|c|}{ Total Biaya Tidak Tetap } & - & 64.575 .000 \\
\hline \multicolumn{2}{|c|}{ Rata-rata Biaya Tidak Tetap } & - & 2.017.968 \\
\hline
\end{tabular}

Pada Tabel 3, menunjukkan bahwa jenis biaya tidak tetap ada 4 macam yaitu : biaya benih yang dikeluarkan sebesar Rp 30.255.000, biaya pupuk sebesar Rp 15.370.000, biaya obat-obatan sebesar Rp 5.580.000, dan biaya tenaga kerja sebesar Rp13.370.000. maka total rata-rata biaya tidak tetap yang dikeluarkan petani responden dalam melakukan kegiatan produksi kakao adalah $\mathrm{Rp} 64.575 .000$ selama 1 (satu) tahun produksi, Rp jelasnya dapat dilihat pada Tabel 4.

Tabel 4. Rata-rata biaya produksi yang dikeluarkan petani kakao responden di Desa Taulo Kecamatan Alla' Kabupaten Enrekang

\begin{tabular}{|c|c|c|c|}
\hline No. & Jenis Biaya & Nilai Biaya (Rp) & Rata-rata (Rp) \\
\hline 1. & Biaya Variabel & 64.575 .000 & 2.017 .968 \\
\hline 2. & Biaya Tetap & 41.130 .000 & 1.285 .312 \\
\hline & Total Biaya & 105.705 .000 & 3.303 .280 \\
\hline
\end{tabular}

Tabel 4 dapat dilihat bahwa per tahun, dan biaya tetap sebesar Rp besarnya biaya variabel $\mathrm{Rp} 64.575 .000 \quad 41.130 .000$ pertahun sehingga rata-rata
5.381.250 selama 1 (satu) bulan produksi, dan Rp 2.017.968 per 1 (satu) orang produksi.

Biaya total adalah jumlah biaya tetapa dan biaya variabel. Setelah beberapa jenis biaya usahatani, maka dapat digambarkan seluruh biaya usahatani, dapat dikeluarkan petani responden (Suratiyah, 2009). Untuk lebih c. Total Biaya Produksi ( Total Cost) 
total biaya produksi yang dikeluarkan oleh petani kakao responden adalah sebesar Rp 105.705.000 selama 1 (satu) tahun produksi,Rp 8.705.000 selama 1 (satu) bulan produksi, Rp 3.303.280 per 1 (satu) orang produksi.

\section{Penerimaan}

Ambarsari et al. (2014) menyatakan penerimaan adalah hasil perkalian antara hasil produksi yang telah dihasilkan selama proses produksi dengan harga jual produk. Penerimaan usahatani dipengaruhi oleh beberapa faktor, antara lain: luas usahatani, jumlah produksi, jenis dan harga komoditas usahatani yang di usahakan. Penerimaan yang diperoleh petani kakao responden di Desa Taulo, Kecamatan Alla, Kabupataen Enrekang dapat dilihat pada tabel 5 .

Tabel 5. Rata-rata penerimaan yang diperoleh petani kako responden di Desa Taulo Kecamatan Alla' Kabupaten Enrekang

\begin{tabular}{ccc}
\hline No. & Uraian & Jumlah \\
\hline 1. & Produksi $(\mathrm{Kg})=(\mathrm{Q})$ & 371.875 \\
2. & Harga/kg $(\mathrm{Rp})=(\mathrm{P})$ & 20.000 \\
3 & Total penerimaan $(\mathrm{Rp})=\mathrm{Q} \times \mathrm{P}$ & 7.437 .500 \\
\hline
\end{tabular}

Tabel 5 berdasarkan hasil analisis yang telah dilakukan pada usaha tani kakao di Desa Taulo Kecamatan Alla Kabupaten Enrekang total penerimaan ynag diperoleh petani responden yaitu dimana total produksi dikali dengan harga jual sehinggan rata-rata produksi biji kakao kering yang diterima responden sebanyak $371.875 \mathrm{Kg}$ dengan harga jual sebesar Rp 20.000 maka diperoleh ratarata penerimaan petani kakao responden sebesar Rp 15.437.

\section{Pendapatan}

Pendapatan adalah perkalian antara produksi yang diperoleh dengan harga jual dan biasanya produksi berhubungan negatif dengan harga, artinya harga akan turun ketika produksi berlebihan
Soekartawi (2002). Pendapatan petani kakao responden di Desa Taulo Kecamatan Alla Kabupaten Enrekang dapat diperoleh dengan rumus $\pi=\mathrm{TR}-$ TC, Diketahui bahwa jumlah total produksi kakao yang diperoleh dari usaha tanaman kakao Rp 4.134.220.

\section{Analisis R/C Ratio}

$\mathrm{R} / \mathrm{C}$ ratio adalah perbandingan antara penerimaan total dengan biaya total. Semakin besar $\mathrm{R} / \mathrm{C}$ ratio maka akan semakin besar pula keuntungan yang diperoleh petani. Hal ini dapat dicapai bila petani mengalokasikan faktor produksi dengan lebih efisien (Soekartawi, 2001).

Diketahui bahwa jumlah penerimaan yang diperoleh dari usaha 
tanaman kakao yaitu $\mathrm{Rp}$ layak untuk dijalankan dan 7.437.500sedangkan total biaya dikembangkan.

produksi Rp 3.303.280 Maka dapat dihitung nilai dari $\mathrm{R} / \mathrm{C}$ rationya yaitu 2,25 . artinya bahwa pengeluaran sebesar Rp 1 memberikan pendapatan sebesar 2,25 berdasarkan kriteria yang ada, maka usahatani petani kakao yang dilaksanakan oleh petani responden Desa Taulo Kecamatan Alla Kabupaten Enrekang

\section{Strategi Pengembangan Usaha}

\section{Tani Kakao}

Hasil analisis Interpretative Struktural Modeling (ISM) usaha tani kakoa menunjukkan bahwa 12 subelemen, semua sub elemen merupakan program yang berperan penting dalam strategi usaha tani kakao.

Tabel 6. Perbandingan bobot DP-D Program Strategi Pengembangan Usaha Tani Kakao

\begin{tabular}{|c|c|c|c|}
\hline \multirow{2}{*}{ Posisi } & \multirow{2}{*}{ Sub Elemen } & \multicolumn{2}{|c|}{ Bobot } \\
\hline & & DP & D \\
\hline & 1. Pembinaan kelompok tani dan gapoktan & 1,00 & 0,66 \\
\hline & 2. Rehabilitas tanaman kakao & 0,91 & 0,66 \\
\hline & 3. Peningkatan kualitas produk/mutu biji kakao & 0,91 & 0,66 \\
\hline & 4. Peningkatan peran penyuluhan & 0,83 & 0,66 \\
\hline & 5. Pengelolaan pasca panen & 0,75 & 0,66 \\
\hline & 6. Pengembangan produktivitas lahan & 0,75 & 0,66 \\
\hline & 7. Pengembangan pemasaran produksi & 0,75 & 0,75 \\
\hline & 8. Pemberantasan hama dan penyakit & 0,75 & 1,00 \\
\hline & 9. Peningkatan sarana produksi & 0,66 & 0,66 \\
\hline & 10. Peningkatan agroimpit & 0,66 & 1,00 \\
\hline & 11. Pengstabilan harga & 0,58 & 0,83 \\
\hline Depende & 12. Peningkatan akses permodalan & 0,5 & 0,83 \\
\hline & Rata-rata & 0,68 & 0,75 \\
\hline
\end{tabular}

\section{Program Strategi Diposisi Lingkage}

Hasil analisis Interpretative Struktural Modeling (ISM) menunjukkan bahwa ada 11 sub elemen yang berada diposis linkage yaitu : (2). Pembinaan kelompok tani/gapoktan, (1). Rehabilitas tanaman kakoa, (6). Peningkatan kualitas produk/mutu biji kakao, (4). Peningkatan peran penyuluhan, (3). Pengelolaan pasca panen, (5). Pengembangan produktivitas lahan, (8). Pengembangan pemasaran produksi, (12) pemberantasan hama dan penyakit, (11). Peningkatan sarana produksi, (10). Peningkatan agroimput, (7). Pengstabilan harga.

Program strategi pengembangan usaha tanaman kakao yang berada pada posisi lingkage adalah pembinaan kelompok tani/gapoktan perlu dilakukan secara berkesinambungan, di arahkan pada perubahan pola pikir petani dalam 
menerapkan sistem agribisnis, pembinaan kelembagaan petani juga diarahkan untuk menumbuhkan kembangkan gapoktan dalam menjalankan fungsinya, serta meningkatkan kapasitas gapoktan. mengembangkan kelompok tani berarti membangun kemauan dan kepercayaan pada diri sendiri agar dapat terlibat secara aktif dalam pembangunan. Disamping itu agar mereka dapat bergerak secara teroganisir dan berdayaguna. Suatu gerakan kelompok tani yang tidak teroganisir dan tidak mengikuti kerjasama menurut polapola yang maju, tidak akan memecahkan permasalahan yang dihadapi petani (Suntoro, 2007).

Program strategi selanjutnya adalah rehabilitas tanaman kakao merupakan program strategi yang sangat penting dalam meningkatkan produktivitas tanaman kakao, tanaman kopi dapat kita pangkas mulai dari cabang sampai ke batang, tanaman kakao bias dengan melakukan penyambungan pada pucuk maupun batang program in ibis adi lakukan pada tanaman kakao yang masih kecil maupun tanaman kakao yang sudah tua dan tidak berproduksi lagi. Menurut Suhendi (2008), dengan teknik sambung samping, petani masih dapat memanen buah kakao dari batang bawah selama batang atasnya belum berbuah. Tanaman hasil sambung samping mulai dapat dipetik buahnya pada umur 18 bulan setelah disambung, dan pada 22-umur 3 tahun mampu menghasilkan 15 buah/pohon.

Program strategi selanjutnya adalah peningkatan kualitas produk/mutu biji kakao Rendahnya produktivitas dan mutu kakao Indonesia terutama disebabkan oleh beberapa hal, antara lain karena biji kakao yang diperdagangkan oleh petani pada umumnya tidak difermentasi terlebih dahulu, padahal mutu biji dan harga jual kakao yang telah difermentasi lebih baik daripada yang belum difermentasi dan patokan harga di pasar internasional berdasarkan biji kakao yang telah difermentas. Kadar biji slaty (biji tidak terfermentasi) berhubungan kuat dengan proses fermentasi yang singkat dan tidak sempurna, serta proses fermentasi yang terjadi secara tidak merata ke seluruh biji kakao, yang ditandai biji kakao berwarna ungu keabu-abuan (Ariyanti, 2017).

Program strategi selanjutnya adalah peningkatan peran penyuluhan yaitu dapat memberikan pemahaman kepada petani kakao dengan cara Penyuluh memahami keinginan petani dan mampu mewujudkan wadah yang lebih baik untuk petani menyampaikan aspirasi mereka. Penyuluh dalam penyuluhan di pedesaan mengubah 
pola pikir petani, bukan mengubah cara bertani. Penyuluhan pertanian bukan mengajarkan petani, tetapi mengajar petani. Yang menjadi titik berat adalah pemberdayaan petani agar menjadi manusia subyek pembangunan pertanian, bukan hanya transfer teknologi. Penyuluhan pertanian merupakan agen perubahan yang langsung berhubungan dengan petani. Fungsi utamanya yaitu mengubah perilaku petani dengan pendidikan non formal sehingga petani mempunyai kehidupan yang lebih baik secara berkelanjutan. Penyuluh dapat mempengaruhi sasaran dalam perannya sebagai motivator, edukator, dinamisator, organisator, komunikator, maupun sebagai penasehat petani (Jarmie 2000).

Program strategi selanjutnya adalah pengelolaan pasca panen adalah kegiatan yang penting yang masuk dalam usaha tani. Pentingnya penanganan pasca panen berdampak pada harga jual komoditas. Apabila penanganan pasca panennya tepat maka kualitas hasil terjaga dan harga komoditis tetap mengikuti harga pasar, sedangkan jika kualitas menurun maka harga komoditi lebih rendah dari pada harga pasar. biji kakao memiliki citarasa yang lemah. Penelitian yang dilakukan oleh Misnawi (2002) menunjukkan pada biji kakao yang tidak difermentasi tidak berbentuk aroma coklat ketika proses penyangraian bahkan menghasilkan rasa kelat dan pahit. Kualitas biji kakao yang telah terfermetasi menghasilkan biji kakao yang memiliki citarasa dan aroma yang lebih baik di bandingkan dengan tanpa fermentasi. Hal ini dikarenakan dalam proses fermentasi timbul rasa dan aroma pada biji kakao sebagai akibat dari berbagai reaksi kimia dan biokimia selama fermentasi tersebut ( Haryadi dan Supryanto, 2011).

Program strategi selanjutnya adalah pengembangan produktivitas lahan, salah satu hal yang sangat penting dalam pengembangan produktivitas lahan yaitu tenaga kerja, modal, tehnologi dan lahan. Gaiha and Imai (2008) mengkaji determinan pertumbuhan pertanian, determinan tenaga kerja pertanian dan tingkat upah di negaranegara berkembang. Hasil penelitiannya ditemukan bahwa mesin traktor, lahan yang teririgasi, penggunaan pupuk, tenaga kerja pertanian berpengaruh positif terhadap produktivitas lahan pertanian.

Program strategi selanjutnya adalah pengembangan pemasaran produksi yaitu strategi untuk menawarkan produk ke pasar atau pedagang, untuk memenuhi dan memperbaiki produk yang ada atau menambah banyaknya ragam produk yang 
di hasilkan dan di pasarkan, yang mana proses pengembangan produk itu sendiri biasanya di lakukan secara terus menerus. Pengembangan produk yaitu mengembangkan produk supaya bisa lebih baik dan dapat menarik minat konsumen serta bisa lebih bersaing dengan seluruh pesaing yang ada Menurut Kotler dan Keller (2009).

Program strategi selanjutnya adalah pemberantasan hama dan penyakit, hama dan penyakit pada tanaman merupakan salah satu kendala yang sangat mengganggu dalam usaha pertanian, serangan pada tanaman dapat di serang secara mendadak dan dapat bersifat meluas sehingga dalam waktu yang relative singkat seringkali dapat mematikan seluruh tanaman dan dapat menimbulkan gagal panen. Meningkatnya serangan OPT. Budidaya kakao menghadapi banyak kendala di lapangan, antara lain penyakit dan hama tanaman yang dapat menurunkan kuantitas dan kualitas produksi kakao. Salah satu penyakit utama pada tanaman kakao di Indonesia adalah penyakit busuk buah (blackpod) yang disebabkan oleh $\mathrm{P}$. palmivora (Butl). Butl. Penyakit yang sama juga diketahui menyerang tanaman kakao di berbagai negara penghasil kakao. Penyakit busuk buah di lapangan menyebabkan kerugian yang bervariasi besarnya antara satu daerah dengan daerah lainnya di Indonesia bahkan di antar negara. Secara umum, besarnya kerugian antara 20-30\% per tahun dapat terjadi akibat infeksi penyakit busuk buah pada pertanaman kakao di lapangan dilaporkan infeksi penyakit busuk buah menyebabkan menurunnya total kakao dunia hingga sebesar 44\%/tahun (Van der Vossen, 1997).

Program strategi selanjutnya adalah peningkatan sarana produksi sarana produksi pertanian merupakan salah satu faktor yang sangat penting dalam mendukung perkembangan atau kemajuan pertanian. Pupuk dan pestisida adalah sarana produksi pertanian utama yang paling banyak diperlukan petani dalam kegiatan pertanian.

Program strategi selanjutnya adalah peningkatan agroimput merupakan hal yang sangat penting keberadaannya karna tanpa adanya pupuk dan pestisida maka tanaman tidak akan tumbuh dengan baik dan produksi pertanian akan menurun tanpa menggunakan pupuk dan pestisida.

Program strategi selanjutnya adalah pengstabilan harga. Harga kakao tentunya menjadi salah satu yang sangat penting untuk di upayakan. Untuk mengstabilkan harga kakao perlu untuk membentuk 
koperasi. Tujuan dibentuknya koprasi petani dimaksudkan untuk menjaga stabilitas harga jual kopi ditingkat petani agar tidak terpuruk pada saat panen raya tiba.

\section{Program Strategi Dependent}

Hasil analisis interpretative Structural Modeling (ISM) menunjukkan bahwa ada 1 program yang merupakan program strategi pengembangan usaha tani kakao yaitu 9. Peningkatan akses permodalan. program yang ada pada posisi ini tidak bebas artinya semua bergantung pada tindakan terhadap subelemen lainnya. Kecilnya Driver power (DP) menunjukkan bahwa sub-elemen tidak menjadi stategi pengembangan usaha tani kakao, sedangkan dependen (D) menunjukkan bahwa ketergantungannya terhadap sub-elemen lainnya besar artinya sub-elemen yang ada diposisi ini tidak bebas artinya yang ada diposisi ini tidak penting atau tidak menjadi strategi pengembangan usaha tani kakao

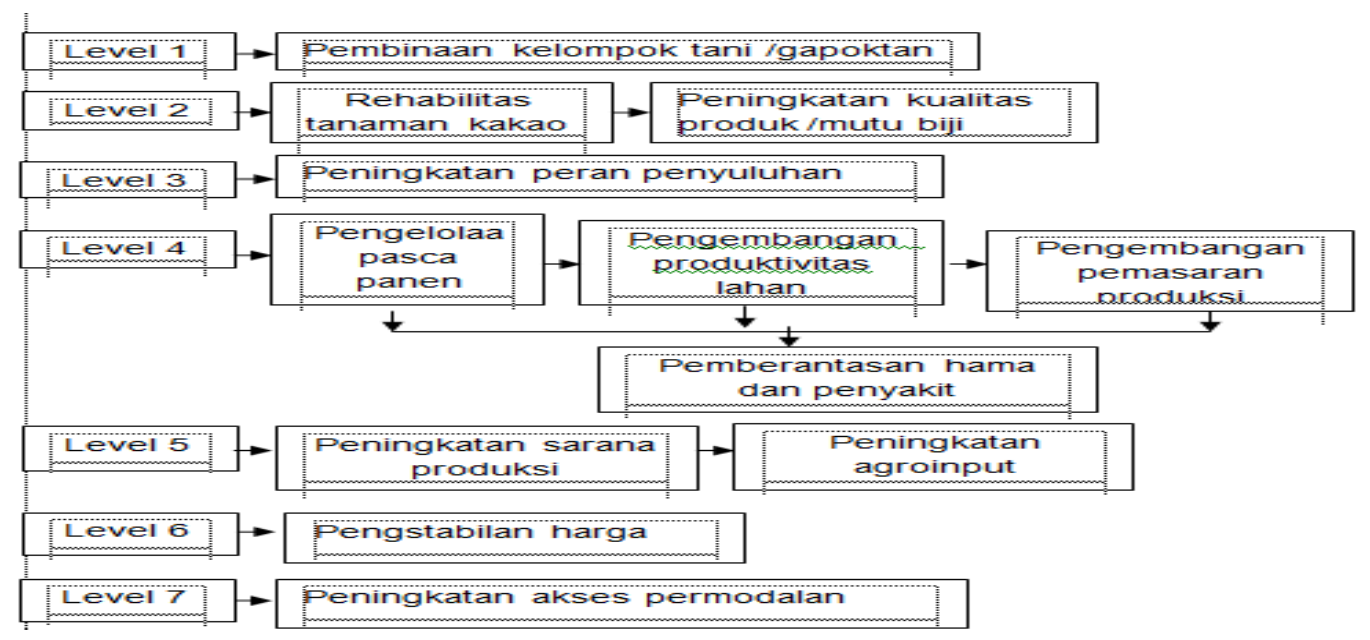

Gambar 1B. Model Structural program strrategi yang perlu dilakukan untuk pengembangan usaha tani kakao.

Gambar 1 menunjukkan bahwa yang berada pada level 1 ada 1 strategi pengembangan usaha tani kakao yang berarti bahwa strategi pengembangan usaha tanaman kakao yang sangat diperlukan adalah Pembinaan kelompok tani/gapoktan. strategi tersebut harus dilakukan untuk pengembnagan usaha tani kakao. Menurut Soedijanto (1996), agar kelompok tani dapat berkembang secara dinamis, maka harus dikembangkan jenis-jenis kemampuan kelompok tani yang terdiri dari (1) fungsi kelompok dalam mentebarluaskan informasi kepada anggota, (2) fungsi kelompok dalam pengadaan fasilitas dan 
sarana produksi, (3) fungsi kelompok tani dalam merencanakan kegiatn kelompok, (4) fungsi kelompok dalam mengarahkan anggota melaksanakan dan menaati perjanjian, dan (5) fungsi kelompok dalam penerapan teknologi panca usaha kepada para anggota.

\section{KESIMPULAN DAN SARAN}

Hasil penelitian dan pembahasan dapat ditarik kesimpulan bahwa pendapatan yang diperoleh usahatani tanaman kakao di Desa Taulo Kecamatan Alla Kabupaten Enrekang adalah sebanyak Rp. 4.134.220. Usahatani tanaman kakao di Desa Taulo Kecamatan Alla Kabupaten Enrekang layak untuk dikembangkan dengan nilai analisis R/C Ratio sebesar 2,25. Program keinginan yang strategis dalam upaya pengembangan usaha tani kakao berupa pembinaan kelompok tani/gapoktan, rehabilitas tanaman kakoa, Peningkatan kualitas produk/mutu biji kakao, peningkatan peran penyuluhan, pengelolaan pasca panen, pengembangan produktivitas lahan, pengembangan pemasaran produksi, pemberantasan hama dan penyakit, peningkatan sarana produksi, peningkatan agroimput, pengstabilan harga.

\section{DAFTAR PUSTAKA}

Dukungan Sosial Pada Mahasiswa yang sedang Menyusun Skripsi (Studi Fenomenologis Pada Mahasiswa Fakultas Psikologi Undip). Jurnal Psikologi Undip, 12 (1), 69-81.

Ambarsari,. 2014. Analisis pendapatan dan profitabilitas usahatani padi (Oryza sativa, 1.) di Kabupaten Indramayu. J. Agri Wiralodra.

Arikunto, 2002. Prosedur Penelitian Suatu Praktek. Rineka Cipta. Jakarta.

Ariyanti, -M., 2017. Karakteristik mutu biji kakao (Theobroma cacao L) dengan perlakuan waktu fermentasi berdasar SNI 2323-2008. Jurnal Industri Hasil Perkebunan

Firdaus, Muhammad. 2008. Manajemen Agribisnis. Jakarta Jakarta:Bumi Aksara

Gaiha, Raghav and K. Imai. 2008. Agricultural Growth, Employment, and Wage Rates in Developing Countries in Berlin Workshop Series. World Bank.

Haryadi, dan Supriyanto. 2001. Bahan AjaranPengolahan Kakao Menjadi Bahan Pangan.Yogyakarta : Pau Pangan Dan Gizi Universitas Gadjah Mada

Jarmie MJ. 2000. Peranan Ilmu Penyuluhan Menuju Pembangunan Pertanian yang Berwawasan Agribisnis dalam.

Kotler, Philip dan Keller, 2009. Manajemen Pemasaran, Edisi 13, Jilid 1 dan 2, Erlangga, Jakarta.

Misnawi, E. Suharyanto, Mulato, S., Widyotomo (Edisi 02). 2002. Pengolahan Coklat. Fatemta IPB: Bogor.

Soekartawi. 2006. Analisis Usahatani. UI Press. Jakarta.

Soekartawi. 2002. Analisis Keuntungan dan Kelayakan Usaha Pembuatan Tahu di Kelurahan Liabuka Kecamatan Bingi Kota Bau-Bau. 
Program Studi Agribisnis. Fakultas Pertanian. Universitas Halu Oleo Kendari.

Soekarwati. 2001. Pengantar Agroindustri. Jakarta : PT Raja Grafindo Persada.

Suntoro, A.W. 2007. Petani : Pahlawan Kehidupan yang Terabaikan. Solo Pos, 21 April 2007.

Soedijanto D. 1996. Keefektifan Kelompok Tani Dalam Meningkatkan Produksi Hasil Pertanian. Disertasi. Bogor : Institut Pertanian Bogor.

Vander vossen, H.A.M. 1997. Strategies of Vareity Improvement on Cocoa with Emphasis on Durable Disease Resistance. INGENIC. Reading, UK. 32p. 